\title{
Influence of temperature on Ranavirus infection in larval salamanders Ambystoma tigrinum
}

\author{
Santos Rojas, Kathryn Richards, James K. Jancovich, Elizabeth W. Davidson* \\ School of Life Sciences, Arizona State University, Tempe, Arizona 85287-4501, USA
}

\begin{abstract}
Temperature strongly influenced percent mortality and time to death of salamanders exposed to the Ambystoma tigrinum virus (iridovirus) (ATV). Most salamanders survived when exposed at $26^{\circ} \mathrm{C}$, whereas all died at $18^{\circ} \mathrm{C}$ and nearly all died at $10^{\circ} \mathrm{C}$. Some asymptomatic salamanders that survived $60 \mathrm{~d}$ at 10 or $26^{\circ} \mathrm{C}$ were found to be carrying virus. Polymerase chain reaction (PCR) confirmed the presence of virus in ATV-exposed salamanders but was found to be less sensitive than cell culture in detecting ATV at low concentrations. PCR products were $100 \%$ identical to ATV in the major capsid protein sequence. Virus titer was higher in salamanders held at $10^{\circ} \mathrm{C}$ than at $18^{\circ} \mathrm{C}$ but little virus, if any, was present in the small number of salamanders that died at $26^{\circ} \mathrm{C}$. These results may help explain periodic viral epizootics in field populations of $A$. tigrinum where water temperatures fluctuate widely.
\end{abstract}

KEY WORDS: Epizootic $\cdot$ Cell culture $\cdot$ Iridovirus $\cdot$ Mortality

\section{INTRODUCTION}

Massive periodic die-offs of the endangered Sonoran tiger salamanders Ambystoma tigrinum stebbinsi in the San Rafael Valley in southern Arizona, USA (Collins et al. 1988), were found to be caused by Ambystoma tigrinum virus (ATV) (family Iridoviridae, genus Ranavirus; Jancovich et al. 1997). In the laboratory at 20 to $22^{\circ} \mathrm{C}$, salamanders generally die about 10 to $14 \mathrm{~d}$ following exposure to ATV. Symptoms include white skin polyps, lethargy, bloody gills, mucus from the cloaca and internal bleeding. Similar viruses have been found in Saskatchewan (Canada), North Dakota, Colorado and several other sites in Arizona (Bollinger et al. 1999, Carey et al. 2003, Docherty et al. 2003, Jancovich et al. 2005).

Ambystoma tigrinum experience daily and seasonal water temperature fluctuations ranging from 5 to $30^{\circ} \mathrm{C}$ in their natural habitats in Southern Arizona (Snyder 1998). In Northern Arizonan A. tigrinum habitats, summer temperatures range from ca. $14^{\circ} \mathrm{C}$ at $2 \mathrm{~m}$ depth to as high as $23.5^{\circ} \mathrm{C}$ in the littoral zone, with tempera- tures varying 3 to $5^{\circ} \mathrm{C}$ during each day (Holomuzki 1986). A. tigrinum is reported to prefer $25^{\circ} \mathrm{C}$ and its activity level increases above $15^{\circ} \mathrm{C}$. This salamander has been observed to move to shallow water during the day and deep water at night during the winter, but movement was random during the spring and summer (Lucas \& Reynolds 1967, Whitford \& Massey 1970, Stauffer et al. 1983).

Environmental temperature influences physiological mechanisms, including metabolism, behavior and potentially immunity of poikilotherms. For example, allograft rejection in newts is significantly delayed at temperatures below $23^{\circ} \mathrm{C}$ (Cohen 1966). In cell culture, ATV can multiply between 15 and $31^{\circ} \mathrm{C}$ (Jancovich 1999), which is very close to the reported preferred temperature range of Ambystoma tigrinum (16 to $31^{\circ} \mathrm{C}$ ) (Lucas \& Reynolds 1967). Our objective in this study was to determine whether infectivity of ATV and survival of infected salamanders differ at 3 temperatures within the range normally found in Arizona salamander habitats in an effort to better understand periodicity of epizootic events in the field. 


\section{MATERIALS AND METHODS}

General methods. ATV was cultured using epithelioma papilloma cyprini (EPC) cells (Fijan et al. 1983). Plaque and TCID $_{50}$ (tissue culture infectious dose $_{50}$; Reed \& Muench 1938) assays employing EPC cells were used to estimate the concentration of virus used in each experiment. Three to 4 mo old Ambystoma tigrinum nebulosum larvae originated from stock held in the laboratory for at least 2 generations. No mortality due to possible virus infection was observed in the rearing facility during this period. During the experiments, each salamander was held individually in $300 \mathrm{ml}$ of water in a Zip Lock $^{\circledR}$ (S. C. Johnson) container and water was changed weekly. Salamanders were fed brine shrimp Artemia sp. 3 times a week and observed daily. Salamanders that died were stored at $-70^{\circ} \mathrm{C}$. At the end of each experiment, body wall samples were taken from all dead larvae and tail clips from surviving salamanders for virus detection. Each sample was placed in a Stomacher $^{\circledR}$ (Seward) bag containing 2 ml of Eagle's Minimum Essential Medium (MEM) + 2\% Fetal Bovine Serum (FBS) + penicillin-streptomycin-neomycin $\left(\mathrm{PSN}_{i}\right.$ Sigma $)+$ diatomaceous earth powder, and homogenized in a Stomacher device. The homogenate was centrifuged at $9000 \times g$ for $10 \mathrm{~min}$ and the supernatant was stored at $-80^{\circ} \mathrm{C}$. Supernatant $(100 \mu \mathrm{l})$ was inoculated onto EPC cells in each well of 12- or 24-well plates, the preparation was rocked for $1 \mathrm{~h}$ and then $1 \mathrm{ml}$ of $\mathrm{MEM}+10 \% \mathrm{FBS}+\mathrm{PSN}$ was added. Cells were incubated at $22^{\circ} \mathrm{C}$ under $5 \% \mathrm{CO}_{2}$ and observed for $2 \mathrm{wk}$ for cytopathic effect (CPE). Samples showing no CPE were passed through 2 further sets of EPC cells to confirm the presence or absence of virus.

To determine the multiplication of virus at the 3 experimental temperatures, replicate EPC cultures in 24-well plates were inoculated with dilutions of ATV and held at 10,18 or $26^{\circ} \mathrm{C}$ for 10 to $16 \mathrm{~d}$. Development of CPE was observed and $\mathrm{TCID}_{50}$ was calculated during incubation.

In order to confirm the results of cell culture assays, homogenized body wall and tail clip tissue from infected and control larvae were subjected to polymerase chain reaction (PCR). PCR was performed on samples of body wall or tail clip tissue from selected salamanders from Expts 1 and 2 (below) to verify virus identity. In total, 75 specimens were subjected to PCR analysis, including 3 untreated controls. Samples included homogenized tissue used previously for virus culture or tissue samples from salamanders frozen at $-70^{\circ} \mathrm{C}$. Two $3 \mathrm{~mm}^{2}$ tissue samples were extracted using $10 \mu \mathrm{l}$ STE $(0.1 \mathrm{M}$ $\mathrm{NaCl}, 0.05 \mathrm{M}$ Tris-HCl pH 7.5, 0.001 M EDTA disodium) and $1 \mu$ l Proteinase K (Promega) and incu- bated at $58^{\circ} \mathrm{C}$ for $3 \mathrm{~h}$, then boiled for $5 \mathrm{~min}$ to inactivate Proteinase K. DNA was extracted using the GeneReleaser (BioVentures) protocol: $20 \mu \mathrm{l}$ GeneReleaser, $65^{\circ} \mathrm{C}$ for $30 \mathrm{~s}, 8^{\circ} \mathrm{C}$ for $30 \mathrm{~s}, 65^{\circ} \mathrm{C}$ for $1.5 \mathrm{~min}$, $97^{\circ} \mathrm{C}$ for $3 \mathrm{~min}, 8^{\circ} \mathrm{C}$ for $1 \mathrm{~min}, 65^{\circ} \mathrm{C}$ for $3 \mathrm{~min}, 97^{\circ} \mathrm{C}$ for $1 \mathrm{~min}, 65^{\circ} \mathrm{C}$ for $1 \mathrm{~min}$ and held at $80^{\circ} \mathrm{C}$. Samples were spun for $3 \mathrm{~min}$ at $16000 \times g$ and supernatant containing DNA was subjected to PCR. Major capsid protein (MCP) primers 4 and 5 (Mao et al. 1997) were used to amplify approximately $500 \mathrm{bp}$ of the 5' end of the MCP gene in a MJ Research Peltier Thermal Cycler. The following steps were used: denaturing at $94^{\circ} \mathrm{C}$ for $5 \mathrm{~min}$ followed by 29 cycles of $94^{\circ} \mathrm{C}$ for $30 \mathrm{~s}, 54^{\circ} \mathrm{C}$ for $30 \mathrm{~s}$ and $72^{\circ} \mathrm{C}$ for $30 \mathrm{~s}$, and a final extension at $72^{\circ} \mathrm{C}$ for $5 \mathrm{~min}$. Upon completion, the amplified DNA fragments were visualized by $1.5 \%$ agarose gel electrophoresis. Ten PCR products (5 from each experiment), were sequenced using automated equipment (ABI 377) at the Arizona State University DNA laboratory.

Confirmation of the presence of ATV was based upon identical sequence within the 5 ' region of the MCP, which differs from that of other published iridovirus sequences (Jancovich et al. 2003). This region exhibits low divergence among 19 isolates from North America but has $21 \mathrm{bp}$ and 9 amino acid differences from the Ranavirus type species, FV3, and greater differences from other iridoviruses (Jancovich et al. 2003, Jancovich et al. 2005).

Expt 1. Thirty 3 mo old salamander larvae were acclimated in refrigerated chambers at 10 or $18^{\circ} \mathrm{C}$ or in an incubator at $26^{\circ} \mathrm{C}$ for $2 \mathrm{wk}$ before half of each group was exposed by water bath immersion to $10^{3}$ plaqueforming units (pfu) of virus $\mathrm{ml}^{-1}$. Half of each group was held as untreated controls. Water was changed with water held at the same temperature as the larvae except that water at $18^{\circ} \mathrm{C}$ was changed with water at room temperature $\left(21^{\circ} \mathrm{C}\right)$ due to lack of holding space. This water dropped to $18^{\circ} \mathrm{C}$ within $10 \mathrm{~min}$. After $60 \mathrm{~d}$ of exposure to ATV, half of the surviving salamanders at all the temperatures were euthanized with tricaine methanesulfonate and tested for virus. The other half of surviving salamanders was euthanized after $90 \mathrm{~d}$ and tested for virus.

Expt 2. In order to confirm the results of Expt 1 and to determine whether rapid mortality observed at $18^{\circ} \mathrm{C}$ was due to thermal shock, we performed a second experiment $1 \mathrm{yr}$ later. In Expt 2, the water at $18^{\circ} \mathrm{C}$ was changed with $18^{\circ} \mathrm{C}$ water, salamanders were held at 10,18 and $26^{\circ} \mathrm{C}$, and each experimental group consisted of 16 control and 16 treated 4 mo old salamanders. Sixty days following exposure to $10^{4} \mathrm{pfu} \mathrm{ml}^{-1}$ of ATV, tissue samples from all surviving larvae and all frozen, dead salamanders were tested for the presence of ATV. 
Statistical analyses. Systat $10^{\circledR}$ statistical package was used to analyze data. Days to death were compared within Expts 1 and 2 using 1-way ANOVA; multiple comparisons were made with the TukeyKramer procedure. For each tempe-rature, a $t$-test was used to compare percent mortality across experiments assuming unequal variances.

\section{RESULTS}

\section{Virus multiplication in cell culture at 3 temperatures}

Viral replication, detected as CPE, occurred very rapidly at $26^{\circ} \mathrm{C}$, reaching maximum $\mathrm{TCID}_{50}$ of $10^{7} \mathrm{ml}^{-1}$ within $8 \mathrm{~d}$ incubation. Control cells did not survive beyond $10 \mathrm{~d}$ at $26^{\circ} \mathrm{C}$. Virus titer developed more gradually at $18^{\circ} \mathrm{C}$, reaching a maximum titer of $10^{6.5} \mathrm{ml}^{-1}$ by $12 \mathrm{~d}$ incubation. At $10^{\circ} \mathrm{C}$, however, CPE developed very slowly, appearing to plateau at a TCID $_{50}$ of ca. $10^{4.75} \mathrm{ml}^{-1}$ by $16 \mathrm{~d}$ (Fig. 1).

\section{Expt 1}

All control salamanders survived at 10 and $18^{\circ} \mathrm{C}$, whereas $20 \%$ of the controls died at $26^{\circ} \mathrm{C}$. No virus was detected in any control salamander by either tissue culture or PCR. By $60 \mathrm{~d}$ after exposure to ATV, $87 \%$ of the salamanders had died at $10^{\circ} \mathrm{C}, 100 \%$ at $18^{\circ} \mathrm{C}$ and $33 \%$ at $26^{\circ} \mathrm{C}$ (Table 1, Fig. 2).

At $26^{\circ} \mathrm{C}$, the first ATV-exposed salamander died after only $7 \mathrm{~d}$ but no virus was found in this animal. Tissue samples from the remaining 4 ATV-exposed salamanders that died at $26^{\circ} \mathrm{C}$ during the $60 \mathrm{~d}$ experimental period demonstrated CPE only after at least 1 wk of incubation, suggesting low virus titer in these animals. Virus was detected in 2 of the salamanders euthanized after $60 \mathrm{~d}$ at $26^{\circ} \mathrm{C}$ only on the second cell culture passage, also indicative of low virus concentration. The remainder of samples from salamanders held at $26^{\circ} \mathrm{C}$ produced no virus after 3 cell culture passages.

Table 1. Mortality and infection status of Ambystoma tigrinum larvae at 3 temperatures

\begin{tabular}{|c|c|c|c|c|c|c|}
\hline \multirow{2}{*}{ Treatment } & \multicolumn{3}{|c|}{ Expt 1} & \multicolumn{3}{|c|}{ Expt 2} \\
\hline & $10^{\circ} \mathrm{C}$ & $18^{\circ} \mathrm{C}$ & $26^{\circ} \mathrm{C}$ & $10^{\circ} \mathrm{C}$ & $18^{\circ} \mathrm{C}$ & $26^{\circ} \mathrm{C}$ \\
\hline Control mortality (\%) & 0 & 0 & 20 & 0 & 0 & 25 \\
\hline Exposed mortality (\%) & 80 & 100 & 33 & 93.8 & 100 & 38 \\
\hline Virus-positive (\%) & 86.7 & 100 & 40 & 93.8 & 100 & 31 \\
\hline $\begin{array}{l}\text { Mean days }(\%) \\
\text { to death (SD) }\end{array}$ & $\begin{array}{l}45.8 \\
(4.0)\end{array}$ & $\begin{array}{l}20.8 \\
(3.5)\end{array}$ & $\begin{array}{c}15.0 \\
(12.7)\end{array}$ & $\begin{array}{c}46 \\
(6.9)\end{array}$ & $\begin{array}{l}20.9 \\
(3.9)\end{array}$ & $\begin{array}{l}24.6 \\
(4.5)\end{array}$ \\
\hline
\end{tabular}

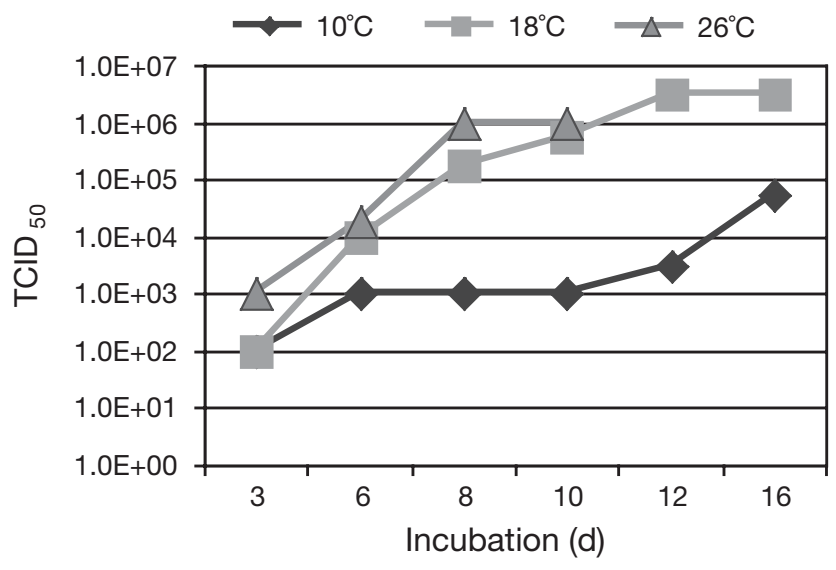

Fig 1. $\mathrm{TCID}_{50}$ of Ambystoma tigrinum virus (ATV) infected epithelioma papilloma cyprini (EPC) cells incubated at 3 temperatures

All salamanders exposed to ATV at $18^{\circ} \mathrm{C}$ died between 15 and $38 \mathrm{~d}$ post-exposure (Fig. 2). Of the salamanders held at $10^{\circ} \mathrm{C}, 80 \%$ died between 49 and $63 \mathrm{~d}$ post-exposure. All salamanders that died during $60 \mathrm{~d}$, and one of the exposed survivors held at $10^{\circ} \mathrm{C}$, were positive for virus by both tissue culture and PCR (Table 1). Cell cultures exposed to tissues from salamanders held at 10 or $18^{\circ} \mathrm{C}$ developed CPE within 2 to $4 \mathrm{~d}$.

\section{Expt 2}

As in Expt 1, no control salamanders died at 10 or $18^{\circ} \mathrm{C}$ but $25 \%$ of controls died at $26^{\circ} \mathrm{C}$ during the $60 \mathrm{~d}$ experimental period. All salamanders exposed to ATV at $18^{\circ} \mathrm{C}$ died between 16 and 28 d post-exposure, and $94 \%$ of those exposed at $10^{\circ} \mathrm{C}$ died between 35 and $56 \mathrm{~d}$ post-exposure (Fig. 2). All salamanders that died during the experiment at 10 or $18^{\circ} \mathrm{C}$ were positive for virus by cell culture assay, but the single surviving individual exposed at $10^{\circ} \mathrm{C}$ was negative. Of 16 salamanders exposed to ATV at $26^{\circ} \mathrm{C}, 6$ died during the $60 \mathrm{~d}$ exposure period but only 1 that died and 2 that survived were positive for virus on first passage through cell culture. Virus was detected in one of the $26^{\circ} \mathrm{C}$-exposed salamanders after second passage and one at third passage through cell culture (Table 1).

Mean days to death in Expt 1 were not statistically different from results of Expt 2 at $\alpha=0.05\left(10^{\circ} \mathrm{C}, \mathrm{p}=0.97 ; 18^{\circ} \mathrm{C}\right.$, $\mathrm{p}=0.96 ; 26^{\circ} \mathrm{C}, \mathrm{p}=0.17$ ). In both experiments, mean days to death at $10^{\circ} \mathrm{C}$ were significantly greater than at 18 or $26^{\circ} \mathrm{C}$ (Table 1).

In Expt 2, we observed that CPE occurred more rapidly in cell culture 
EXPT 1

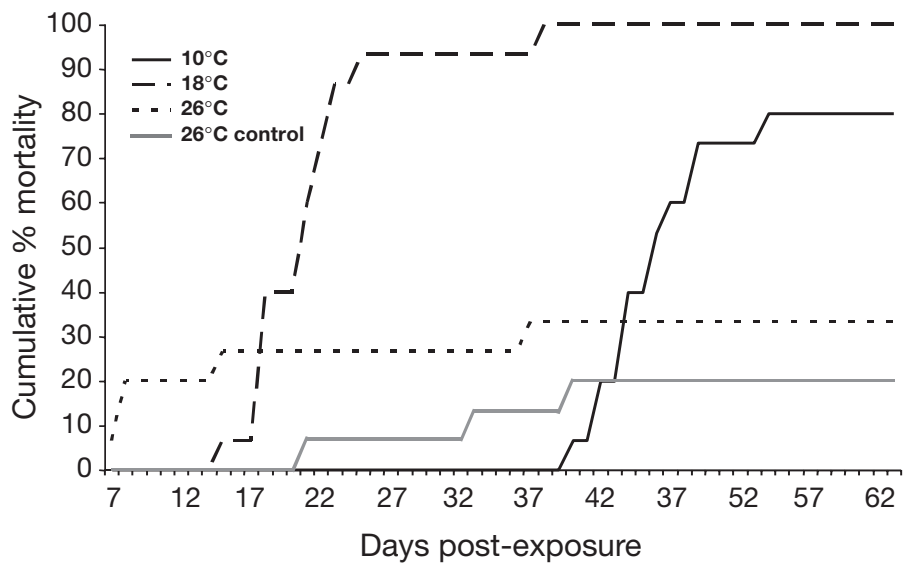

EXPT 2

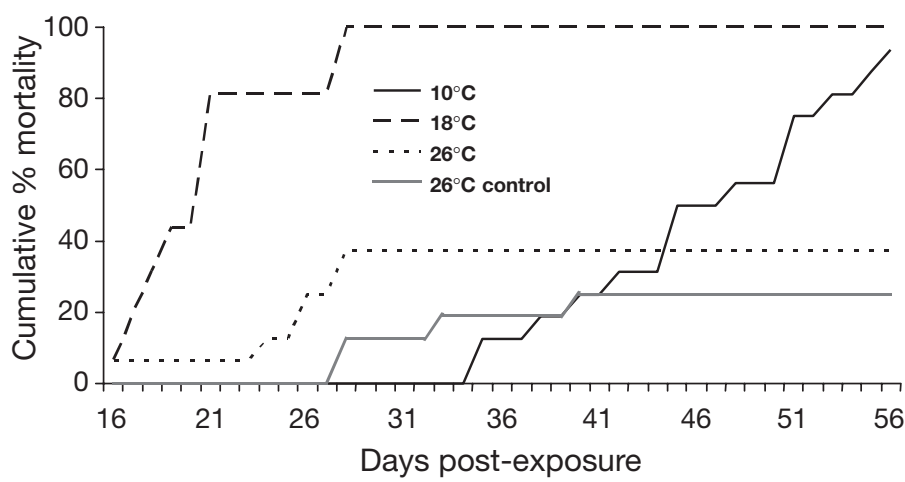

Fig. 2. Cumulative mortality in Expts 1 and 2 at 3 temperatures

assays of specimens that died at $10^{\circ} \mathrm{C}$ than in ones that died at $18^{\circ} \mathrm{C}$, leading to the hypothesis that the salamanders held at $10^{\circ} \mathrm{C}$ may have developed a higher virus titer than those at $18^{\circ} \mathrm{C}$. Samples were taken from the ventral body wall from these salamanders and weighed before homogenization. Samples from $18^{\circ} \mathrm{C}$ salamanders $(X=0.196 \mathrm{~g} ; \mathrm{SD}=0.046 \mathrm{~g}$ ) produced $\mathrm{TCID}_{50}$ values ranging from $10^{4.5}$ to $10^{6.25}$, with the majority of samples at or below $10^{6.0}$. Body wall samples from salamanders exposed at $10^{\circ} \mathrm{C}(\mathrm{X}=0.276 \mathrm{~g}$; $\mathrm{SD}=0.139 \mathrm{~g}$ ) produced $\mathrm{TCID}_{50}$ values ranging from $10^{5.5}$ to $10^{6.75}$, with the majority of samples above $10^{6.0}$. The highest virus titers were found in samples from salamanders that died more than $30 \mathrm{~d}$ after exposure at $10^{\circ} \mathrm{C}$ (Fig. 3).

Salamanders exposed to ATV that eventually died exhibited symptoms of infection similar to those described earlier (Jancovich et al. 1997), including reddening and hemorrhaging on feet and legs, sloughing of skin, heavy mucus excretion from the cloaca, floating and refusal to feed.

\section{Polymerase chain reaction}

Salamanders total of 75 specimens were subjected to PCR analysis. All PCR products from salamanders exposed to ATV ran parallel to ATV positive control products on $1.5 \%$ agarose gels. A small proportion of these bands ran slightly lower than ATV; however, sequencing revealed $100 \%$ identity to ATV in MCP sequence. No control tissue from untreated salamanders produced a PCR product. Tissues from salamanders exposed at $26^{\circ} \mathrm{C}$ that gave positive results after 3 passages in cell culture did not produce detectable PCR products and none of the samples that were negative in cell culture were positive by PCR. All 10 sequenced products were identical to ATV MCP sequence (Jancovich et al. 2003).

\section{DISCUSSION}

We explored the effects of 3 constant temperatures similar to those found in Arizona field sites on survival of Ambystoma tigrinum infected with low dosages of ATV. Our results demonstrate that temperature strongly influences the infectivity, percent mortality and time to death of ATV-infected salamanders (Table 1, Fig. 2). Although salamanders may be killed by ATV at high virus concentrations at $25^{\circ} \mathrm{C}$ (Jancovich 1999), lower dosage exposure more closely mimics the situation in the field, where salamander larvae are probably exposed to virus carried by conspecifics, since no other host or reservoir for ATV has yet been found (Jancovich et al. 2001). Water collected near heavily infected, symptomatic salamanders exposed to ATV in laboratory experiments did not exceed $10^{3}$ to $10^{4} \mathrm{pfu} \mathrm{ml}^{-1}$ (E. W. Davidson unpubl. data). In cell culture, ATV caused CPE more rapidly at $26^{\circ} \mathrm{C}$ than at

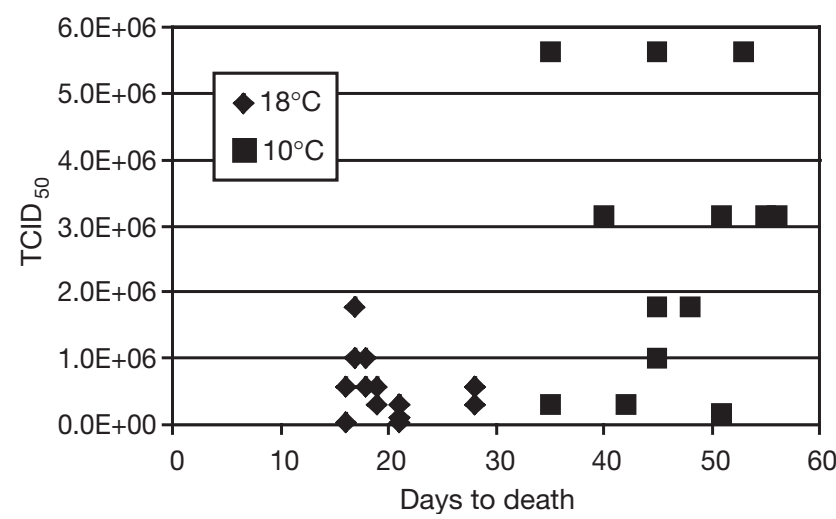

Fig. 3. $\mathrm{TCID}_{50}$ of ATV in body wall samples from Ambystoma tigrinum infected at 18 or $10^{\circ} \mathrm{C}$, versus days to death. Sample weights: $18^{\circ} \mathrm{C}, \mathrm{X}=0.196 \mathrm{~g}(\mathrm{SD}=0.046 \mathrm{~g}) ; 10^{\circ} \mathrm{C}, \mathrm{X}=0.276 \mathrm{~g}$ $(\mathrm{SD}=0.139 \mathrm{~g})$ 
lower temperatures (Fig. 1) and has been shown to multiply in cell culture up to $31^{\circ} \mathrm{C}$ (Jancovich 1999). Failure of salamanders to develop lethal viral infections at $26^{\circ} \mathrm{C}$, therefore, was not due to the inability of the virus to multiply at higher temperatures, but probably to enhanced immune function of the animal itself. ATV was not detected in control larvae by either cell culture or PCR. Samples from infected larvae held at $26^{\circ} \mathrm{C}$ that required 2 or 3 passages in cell culture for detection of virus were negative by PCR. These results suggest that cell culture is a more sensitive method than PCR for detection of low levels of virus in salamander tissue. PCR confirmed that control mortality at $26^{\circ} \mathrm{C}$ was not due to inapparent virus infection triggered by higher holding temperatures and that experimentally challenged salamanders indeed died of ATV infection. MCP primers used in this study are capable of detecting and differentiating between many species of Ranaviruses and should have detected such viruses if they were present (Mao et al. 1997, Marsh et al. 2002).

In Expt 1, weekly water changes of $18^{\circ} \mathrm{C}$ larvae using $21^{\circ} \mathrm{C}$ water could have led to thermal shock, although $10 \mathrm{~min}$ or less were required for the temperature to drop to $18^{\circ} \mathrm{C}$. However, mortality at $18^{\circ} \mathrm{C}$ was quite similar in Expt 2, in which water temperature remained constant, suggesting that thermal shock was not a factor leading to the rapid mortality at $18^{\circ} \mathrm{C}$. At lower temperatures, the salamander immune system is apparently less able to inhibit multiplication of the virus. Humoral-/cell-mediated immune defense mechanisms in frogs and some fish have been shown to be reduced at lower temperatures (Green \& Cohen 1977 , Hardie et al. 1994, Maniero \& Carey 1997, Jozkowicz \& Plytycz 1998, Watson et al. 1998, Carey et al. 1999). Synthesis of antimicrobial skin peptides by Rana sylvatica is inhibited by cold (Matutte et al. 2000), although frog skin peptides can inactivate Ranaviruses at temperatures as low as $0^{\circ} \mathrm{C}$ (Chinchar et al. 2001). Adult newts Diemictylus viridescens required 1.7 times longer to reject allografts at $20^{\circ} \mathrm{C}$ than at $23^{\circ} \mathrm{C}$ (Cohen 1966). The change in allograft rejection time mirrors the dramatic difference found in our study between virus-induced mortality and infectivity at 26 and $18^{\circ} \mathrm{C}$. Taken together, prolonged allograft rejection and enhanced ATV mortality at temperatures below $20^{\circ} \mathrm{C}$ suggest that the function of one or more components of the urodele immune system is sharply inhibited below ca. $20^{\circ} \mathrm{C}$.

Temperatures at or near $18^{\circ} \mathrm{C}$ appear to be optimum for ATV to infect and rapidly kill Ambystoma tigrinum. The mortality of salamanders at $18^{\circ} \mathrm{C}$ appears to be a result of the interaction of rapid viral multiplication with reduced host immune response at this temperature. At colder temperatures $\left(10^{\circ} \mathrm{C}\right)$, time to death is greater but virus titer per animal is increased. Apoptosis of infected cells may be reduced at lower temperatures (Barker et al. 1997), leading to enhanced virus production per cell. A related ranavirus, Frog Virus 3, induces apoptosis in cultured cells within 6 to $7 \mathrm{~h}$ post-infection at $26^{\circ} \mathrm{C}$; however, apoptosis at lower temperatures was not tested (Chinchar et al. 2003). Massive die-offs related to ATV observed in the field in the spring and fall may be related to these temperature-influenced interactions between the salamander immune system and viral multiplication.

The 20 to $25 \%$ control mortality at $26^{\circ} \mathrm{C}$ may be due to lowered oxygen concentrations in the small holding containers, increased bacterial content or general stress, as $26^{\circ} \mathrm{C}$ is near the upper limit of temperatures experienced by Ambystoma tigrinum in its natural habitat (Snyder 1998). Although higher temperature may result in recovery from infection, explaining the low viral titer found in $26^{\circ} \mathrm{C}$-infected salamanders, it may also provide a greater chance for secondary microbial infections (Watson et al. 1998). No evidence of viral infection was found in the $26^{\circ} \mathrm{C}$ control larvae by either cell culture or PCR and these salamanders did not display the characteristic symptoms of ATV infection (Jancovich et al. 1997). Our results suggest that if infected salamanders moved to warmer regions of the habitat, such 'behavioral fever' could inhibit viral mortality due to ATV. A. tigrinum may select specific temperature regions within a pond, but no evidence of basking was reported (Brattstrom 1963). In response to environmental hypoxia, A. tigrinum may seek lower temperatures (Dupré \& Wood 1988). Hypoxia may occur in eutrophic ecosystems such as the small ponds that provide habitat for Arizona salamanders, suggesting a possible link between hypoxia, salamanders seeking lower water temperature and viral epizootics.

Four ATV-exposed salamanders in Expt 1, and 2 in Expt 2 survived at least $60 \mathrm{~d}$ and were asymptomatic but were found to have low levels of virus as detected by cell culture. These results, combined with other recent results from our laboratory (Brunner et al. 2004) demonstrate that sublethal infections can result in viral carrier status in both the laboratory and the field. Such carrier animals can be important reservoirs for virus infection in the field.

Acknowledgements. S.R. and K.R. performed this research as undergraduate students. S.R. was supported by NIH Minority Access to Research Careers GM08491-10; E.W.D., K.R. and J.K.J. were supported by NSF Integrated Research Challenges in Environmental Biology IBN 9977063 and DEB 0213851. We are grateful to L. Rollins-Smith, N. Cohen, J. Collins, J. Brunner and S. Cashins, and to anonymous reviewers for helpful suggestions on the manuscript and statistical assistance. PCR data were added after initial submission at the suggestion of reviewers. Experiments using Ambystoma 
tigrinum were conducted under ASU Institutional Animal Care and Use Committee Permit No. 99-526R, which approved the use of tricaine methanesulfonate for euthanasia.

\section{LITERATURE CITED}

Barker KS, Davis A, Li B, Rollins-Smith LA (1997) In vitro studies of spontaneous and corticosteroid-induced apoptosis of lymphocyte populations from metamorphosing frogs/RU486 inhibition. Brain, Behav Immun 11:119-131

Bollinger TK, Mao J, Schock D, Brigham RM, Chinchar VG (1999) Pathology, isolation and preliminary molecular characterization of a novel iridovirus from tiger salamanders in Saskatchewan. J Wildl Dis 35:413-429

Brattstrom BH (1963) A preliminary review of the thermal requirements of amphibians. Ecology 44:238-255

Brunner JL, Schock DM, Davidson EW, Collins JP (2004) Intraspecific reservoirs: complex life history and the persistence of a lethal ranavirus. Ecology 85(2):560-566

Carey C, Cohen N, Rollins-Smith L (1999) Amphibian declines: an immunological perspective. Dev Comp Immunol 23:459-472

Carey C, Bradford DF, Brunner JL, Collins JP and 5 others (2003) Biotic factors in amphibian population declines. In: Linder GL, Krest SK, Sparling DW (eds) Amphibian decline: an integrated analysis of multiple stressor effects. Society of Environmental Toxicology and Chemistry (SETAC), Pensacola, FL, p 153-208

Chinchar VG, Wang J, Murti G, Carey C, Rollins-Smith L (2001) Inactivation of frog virus 3 and channel catfish virus by esculentin-2P and ranatuerin-2P, two antimicrobial peptides isolated from frog skin. Virology 288:351-357

Chinchar VG, Bryan L, Wang J, Long S, Chinchar GD (2003) Induction of apoptosis in frog virus 3-infected cells. Virology 306:303-312

Cohen N (1966) Tissue transplantation immunity in the adult newt, Diemictylus viridescens. III. The effects of X-irradiation and temperature on the allograft reaction. J Exp Zool 163:231-240

Collins JC, Jones TR, Berna HJ (1988) Conserving genetically-distinctive populations: the case of the Huachuca tiger salamander (Ambystoma tigrinum stebbinsi Lowe). In: Szaro RC, Severson KC, Patton DR (eds) Management of amphibians, reptiles and small mammals in North America. USDA Forest Service GTR-RM-166, Fort Collins $\mathrm{CO}, \mathrm{p}$ 45-53

Docherty DE, Meteyer CU, Wang J, Mao J, Case S, Chinchar VG (2003) Diagnostic and molecular evaluation of three iridovirus associated salamander mortality events. J Wildl Dis 39:556-566

Dupré RK, Wood SC (1988) Behavioral temperature regulation by aquatic ectotherms during hypoxia. Can J Zool 66: 2649-2652

Fijan N, Matasin Z, Petrinic Z, Valpotic I, Zwillenberg LG (1983) Some properties of the epithelioma papulosum cyprini (EPC) cell line from carp Cyprinus carpio. Ann Virol 134:207-220

Green N, Cohen N (1977) Effect of temperature on serum complement levels in the leopard frog, Rana pipiens. Dev Comp Immunol 1:59-64

Editorial responsibility: Peernel Zwart, Utrecht, The Netherlands
Hardie LJ, Fletcher TC, Secombes CJ (1994) Effect of temperature on macrophage activation and the production of macrophage activating factor by rainbow trout leucocytes. Dev Comp Immunol 18:57-66

Holomuzki JR (1986) Predator avoidance and diel patterns of microhabitat use by larval tiger salamanders. Ecology 67 : $737-748$

Jancovich JK (1999) Ambystoma tigrinum virus: identification, detection, transmission, characterization, and taxonomic position. MSc thesis, Arizona State University, Tempe, AZ

Jancovich JK, Davidson EW, Morado JF, Jacobs BL, Collins JP (1997) Isolation of a lethal virus from the endangered tiger salamander Ambystoma tigrinum stebbinsi. Dis Aquat Org 31:161-167

Jancovich JK, Davidson EW, Seiler A, Jacobs BL, Collins JP (2001) Transmission of the Ambystoma tigrinum virus to alternative hosts. Dis Aquat Org 46:159-163

Jancovich JK, Mao J, Chinchar VG, Wyatt C and 7 others (2003) Genomic sequence of a ranavirus associated with salamander mortalities in North America. Virology 316: 90-103

Jancovich JK, Davidson EW, Parameswaran N, Mao J, Chinchar VG, Collins JC, Jacobs B, Storfer A (2005) Emergence of an amphibian disease due to human-enhanced spread. Mol Ecol 14:213-224

Jozkowicz A, Plytycz B (1998) Temperature but not season affects the transplantation immunity of anuran amphibians. J Exp Zool 281:58-64

Lucas EA, Reynolds WA (1967) Temperature selection by amphibian larvae. Physiol Zool 40:159-171

Maniero GD, Carey C (1997) Changes in selected aspects of immune function in the leopard frog, Rana pipiens associated with exposure to cold. J Comp Physiol B 167: 256-263

Mao J, Hedrick RP, Chinchar VG (1997) Molecular characterization, sequence analysis, and taxonomic position of newly isolated fish iridovirueses. Virology 229:212-220

Marsh IB, Whittington RJ, O'Rourke B, Hyatt AD, Chisholm O (2002) Rapid differentiation of Australian, European and American ranaviruses based on variation in major capsid protein gene sequence. Mol Cell Probes 16:137-151

Matutte B, Storey KB, Knoop FC, Conlon JM (2000) Induction of synthesis of an antimicrobial peptide in the skin of the freeze-tolerant frog, Rana sylvatica, in response to environmental stimuli. FEBS Lett 483:135-138

Reed LJ, Muench H (1938) A simple method of estimating fifty percent endpoints. Am J Hygiene 27:493-497

Snyder JD (1998) Ecology, management, and intellectual history of native and introduced species. MSc thesis, Arizona State University, Tempe, AZ

Stauffer JR Jr, Gates JE, Goodfellow WL (1983) Preferred temperature of two sympatric Ambystoma larvae: a proximate factor in nich segregation? Copeia 1983:1001-1005

Watson LR, Milani A, Hedrick RP (1998) Effects of water temperature on experimentally-induced infections of juvenile white sturgeon (Acipenser transmontanus) with the white sturgeon iridovirus (WSIV). Aquaculture 166: 213-228

Whitford WG, Massey M (1970) Responses of a population of Ambystoma tigrinum to thermal and oxygen gradients. Herpetologica 26:372-376

Submitted: July 29, 2002; Accepted: August 30, 2004

Proofs received from author(s): December 6, 2004 